\title{
The effect of grape seed and grape marc meal extract on milk performance and the expression of genes of endoplasmic reticulum stress and inflammation in the liver of dairy cows in early lactation
}

\author{
D. K. Gessner, ${ }^{\star}$ C. Koch,† F.-J. Romberg,† A. Winkler,‡ G. Dusel,‡ E. Herzog,§ E. Most, ${ }^{*}$ and K. Eder*1 \\ *Institute of Animal Nutrition and Nutrition Physiology, Justus-Liebig-University Giessen, Heinrich-Buff-Ring 26-32, 35392 Giessen, Germany \\ †Educational and Research Centre for Animal Husbandry, Hofgut Neumuehle, 67728 Muenchweiler an der Alsenz, Germany \\ ‡Department Life Sciences and Engineering, University of Applied Sciences, 55411 Bingen am Rhein, Germany \\ §Institute of Agronomy and Plant Breeding II, Justus-Liebig-University Giessen, Heinrich-Buff-Ring 26-32, 35392 Giessen, Germany
}

\section{ABSTRACT}

During the periparturient phase, cows are typically in an inflammation-like condition, and it has been suggested that inflammation associated with the development of stress of the endoplasmic reticulum (ER) in the liver contributes to the development of fatty liver syndrome and ketosis. In the present study, we investigated the hypothesis that feeding grape seed and grape marc meal extract (GSGME) as a plant extract rich in flavonoids attenuates inflammation and ER stress in the liver of dairy cows. Two groups of cows received either a total mixed ration as a control diet or the same total mixed ration supplemented with $1 \%$ of GSGME over the period from wk 3 prepartum to wk 9 postpartum. Dry matter intake during wk 3 to 9 postpartum was not different between the 2 groups. However, the cows fed the diet supplemented with GSGME had an increased milk yield and an increased daily milk protein yield. Cows supplemented with GSGME moreover had a significantly reduced mRNA abundancy of fibroblast growth factor $(F G F)$ 21, a stress hormone induced by various stress conditions, in the liver in wk 1 and 3 postpartum. In contrast, mRNA abundances of a total of 3 genes involved in inflammation and 14 genes involved in ER stress response, as well as concentrations of triacylglycerols and cholesterol, in liver samples of wk 1 and 3 postpartum did not differ between the 2 groups. Overall, this study shows that supplementation of GSGME did not influence inflammation or ER stress in the liver but increased milk yield, an effect that could be due to effects on ruminal metabolism.

Key words: dairy cow, liver, inflammation, grape seed and grape marc meal extract

Received February 18, 2015.

Accepted August 12, 2015.

${ }^{1}$ Corresponding author: klaus.eder@ernaehrung.uni-giessen.de

\section{INTRODUCTION}

The transition period spanning the time period between wk 3 prepartum and wk 3 postpartum represents the most critical period in the productive life of highyielding dairy cows. During this period, the liver experiences pronounced metabolic stress due to a marked influx of NEFA, which are mobilized from adipose tissue triacylglycerol (TAG) stores due to a severe negative energy balance (Drackley, 1999). Approximately one-third of the whole-body NEFA flux is taken up into the liver and exceeds its oxidation capacity and, thus, promotes liver-associated diseases, such as fatty liver and ketosis (Drackley et al., 2001). Besides this metabolic stress, the liver of early lactating cows is exposed to diverse inflammatory challenges, such as microbial components, pro-inflammatory cytokines, and reactive oxygen species. These inflammatory challenges are resulting from infectious diseases, such as mastitis, endometritis, but also from subacute rumen acidosis and abomasal displacement (Plaizier et al., 2008; Vels et al., 2009; Zebeli and Metzler-Zebeli, 2012), which frequently occur during parturition, the onset of lactation, or both. As a consequence of this, transition dairy cows develop an inflammation-like condition in the liver (Bionaz et al., 2007; Vels et al., 2009), which is evident from the induction of an acute phase response. The acute phase response is characterized by the production of positive acute phase proteins, such as serum amyloid A, haptoglobin, or C-reactive protein, which compete with the production of essential liver proteins, also called negative acute phase proteins, such as albumins, enzymes, lipoproteins, transferrin, or carriers of vitamins and hormones (Carroll et al., 2009). The role of inflammation during transition to lactation for health and performance of dairy cows has been recently highlighted in a review in this journal (Bradford et al., 2015). It has been found that metabolic and inflammatory stress induces stress of the endoplasmic reticulum (ER) in the liver of early lactating cows (Gessner et al., 
2014). Endoplasmic reticulum stress is defined as an imbalance between the folding capacity of the ER and the protein load, with the consequence that unfolded or misfolded proteins accumulate in the ER lumen, thereby disturbing ER homeostasis (Cnop et al., 2012). It is known from studies in humans and rodents that this causes activation of an adaptive response, termed unfolded protein response (UPR), which aims to decrease the unfolded protein load and restore ER function (Cnop et al., 2012). The activation of the UPR, such as observed in rat models of obesity or diabetes or induced by application of chemical ER stress inducers, leads to a variety of symptoms in the liver, which are similar to those observed in periparturient dairy cows. This includes the development of fatty liver (Gentile et al., 2011; Lee et al., 2012; Pagliassotti, 2012), an enhancement of the antioxidant and cytoprotective capacity by activation of Nrf2 (Cullinan et al., 2003; Cullinan and Diehl, 2006; Gessner et al., 2013b), an induction of inflammation (Zhang and Kaufman, 2008; Rath and Haller, 2011), and an induction of FGF21 (Schaap et al., 2013). Therefore, it has been proposed that ER stress-induced UPR contributes to the pathophysiologic conditions commonly observed in the liver of periparturient cows, such as the development of fatty liver, ketosis, or inflammation (Ringseis et al., 2015).

Polyphenols are members of a large family of plantderived compounds classified as flavonoids and nonflavonoids. Polyphenols of the flavonoid class have been shown to exert several beneficial effects in humans and animals. Besides their antioxidative potential, flavonoids have strong antiinflammatory properties. Studies with various models of inflammation such as obese rats, rats fed a high-fat diet or rats challenged with endotoxins, dietary supplementation with various types of flavonoids reduced the level of inflammation in the liver and attenuated the development of hepatic steatosis, which is a typical feature in these animal models (Terra et al., 2009; Bharrhan et al., 2012; Heber et al., 2014). Recently, it has been found that flavonoids are moreover able to attenuate ER stress in liver and muscle cells (Giordano et al., 2014; Rodriguez et al., 2015).

Whereas a great number of studies dealing with antiinflammatory properties of flavonoids has been performed in humans and rodents, less information is available so far about potential beneficial effects of flavonoids in farm animals. In the present study, we investigated the hypothesis that supplementation of flavonoids could reduce inflammation and ER stress in the liver of dairy cows during early lactation. Cows were fed a diet supplemented with grape seed and grape marc meal extract (GSGME), an inexpensive byproduct of wine and grape juice processing, rich in flavonoids.
The most abundant flavonoids in grape seeds (GS) are gallic acid, catechin, epigallocatechin-3-gallate, epigallocatechin, epicatechin-3-gallate, epicatechin, and proanthocyanidins (Auger et al., 2004). Grape marc (GM) contains fewer procyanidins (with the exception of the procyanidin dimer B1) but contains significant amounts of anthocyanins, such as cyanidine 3-glucoside, malividin 3-glucoside, cyanidin, and peonidin, which are absent in GS (Auger et al., 2004). Due to their antioxidant and free radical scavenging activities, GS meal and GM meal are used as feed additives for oxidative stabilization of feedstuff (Bonilla et al., 1999). In recent studies, grape products have been considered as supplements for ruminants, and it has been found that these products are able to reduce methane production, probably due to their high concentrations of tannins, which have inhibitory effects on methanogenic bacteria (Moate et al., 2014; Ishida et al., 2015; Khiaosa-Ard et al., 2015). In contrast, the potential effects of grape products on inflammation and ER stress in the liver of dairy cows have not yet been investigated so far.

\section{MATERIALS AND METHODS}

The study was conducted at the Educational and Research Centre for Animal Husbandry Hofgut Neumuehle in Rhineland-Palatinate (Münchweiler an der Alsenz, Germany) and were approved by the local department for animal welfare affairs (23 177-07/G 12-20-074).

\section{Animals}

Twenty-eight primiparous and multiparous Holstein cows with an average parity number of 2.8 were used as experimental animals for this study. The cows were allocated into 2 experimental groups, either a control group or a group supplemented with GSGME (GSGME group). Multiparous cows were allocated to the groups according to parity number and previous milk performance; heifers were allocated randomly. Each group was composed of 4 primiparous and 10 multiparous cows with an average parity number of 2.8 for the control group and 2.9 for the GSGME group. Body weights of the cows did not differ before parturition (wk 8 prepartum: control group, $692 \pm 21 \mathrm{~kg}$; treatment group, 664 $\pm 21 \mathrm{~kg}$; mean $\pm \mathrm{SE}$ ) or after parturition (wk 2 postpartum: control group, $657 \pm 28 \mathrm{~kg}$; GSGME group, $632 \pm 22 \mathrm{~kg}$; mean $\pm \mathrm{SE}$ ) between the 2 groups. The cows were housed in a freestall barn with boxes bedded with short cut straw. Five days before the expected calving date until $5 \mathrm{~d}$ after calving, the cows were kept separately from the herd in calving pens bedded with short cut straw. During this time, feed intake of the 
individual cows could not be recorded. After cows were transferred to the freestall barn, individual feed intake was recorded by using feed bins, which were equipped with an automatic weighing system (Roughage Intake Control; Insentec B.V., Marknesse, the Netherlands).

\section{Diets}

The experimental period consisted of wk 3 before the expected calving date of the cows to wk 9 postpartum. In the period between wk 3 prepartum and calving, a TMR was calculated to meet the demand of net energy and $\mathrm{CP}$ requirement of a dry cow with a BW of $650 \mathrm{~kg}$ and an assumed DMI of $12 \mathrm{~kg}$ of DM/d, according to German Society of Nutrition Physiology (GfE, 2001; Table 1). After calving, all animals were offered a basal TMR calculated to meet the demand of net energy and $\mathrm{CP}$ requirement for producing $34 \mathrm{~kg}$ of milk, with an assumed daily DMI of $22 \mathrm{~kg}$ (Table 1).

In the time period from 3 wk before the expected calving date until wk 9 postpartum, the basal TMR of the GSGME group were supplemented with 1\% of GSGME (Antaox, Dr. Eckel, Niederzissen, Germany) based on DM content. The GSGME was mixed homogenously into the TMR using a feed mixer. The GSGME product used had a total flavonoid content of $52 \mathrm{mg}$ gallic acid equivalents per gram [according to determination of total polyphenol content by the Folin-Ciocalteu method (Singleton and Rossi, 1965)]. The TMR of the control group was supplemented with $1 \%$ of wheat bran for an energetic adjustment. The TMR was fed once per day at $0730 \mathrm{~h}$. Feed residuals were checked visually daily for sorting behavior of the cows. All cows had free access to drinking water.

\section{Feed Samples and Analyses}

Samples of all feedstuffs were collected every second week and stored at $-20^{\circ} \mathrm{C}$ until analysis. Feed samples were analyzed for crude ash, CP, crude fat, and crude fiber according to the official methods of Verband der Deutschen Landwirtschaftlichen Untersuchungs- und Forschungsanstalten (VDLUFA, 2007). The NDF and ADF were analyzed according to Van Soest et al. (1991). The $\mathrm{NE}_{\mathrm{L}}$ and $\mathrm{CP}$ of the diets were calculated according to the German Society of Nutrition Physiology (GfE, 2001).

\section{Milk and Blood Samples and Liver Biopsies}

Cows were milked twice daily at 0500 and $1530 \mathrm{~h}$ in a combined milking parlor offering space for 8 cows in the herringbone parlor and a side-by-side parlor for 10 cows, manufactured by GEA Farm Technologies (Boenen, Germany). Daily milk yield was recorded electronically via the herd management system Dairy Plan C21 from GEA and stored. From wk 2 to 9 postpartum, milk samples were collected weekly as aliquots

Table 1. Ingredient composition and chemical composition (\% of DM, unless otherwise noted)offered during dry period and lactation to the control group or the grape seed and grape marc meal extract (GSGME) group

\begin{tabular}{|c|c|c|c|c|}
\hline \multirow[b]{3}{*}{ Item } & \multicolumn{2}{|c|}{ Dry period } & \multicolumn{2}{|c|}{ Lactation } \\
\hline & \multicolumn{2}{|c|}{-21 to $0 \mathrm{DIM}$} & \multicolumn{2}{|c|}{1 to $63 \mathrm{DIM}$} \\
\hline & Control & GSGME & Control & GSGME \\
\hline \multicolumn{5}{|l|}{ Ingredient } \\
\hline Grass silage & 30.7 & 30.7 & 22.7 & 22.7 \\
\hline Corn silage & 35.7 & 35.7 & 18.0 & 18.0 \\
\hline Pressed beet pulp silage & 0 & 0 & 12.7 & 12.7 \\
\hline Wheat straw and hay & 6.5 & 6.5 & 4.9 & 4.9 \\
\hline Barley & 6.1 & 6.1 & 10.5 & 10.5 \\
\hline Corn grain, cracked & 6.1 & 6.1 & 10.5 & 10.5 \\
\hline Soybean meal & 0 & 0 & 5.6 & 5.6 \\
\hline Canola meal & 12.6 & 12.6 & 13.1 & 13.1 \\
\hline Wheat bran & 1.0 & - & 1.0 & - \\
\hline GSGME & - & 1.0 & - & 1.0 \\
\hline Vitamin and mineral mix & 0.8 & 0.8 & 0.8 & 0.8 \\
\hline Urea & 0.5 & 0.5 & 0.2 & 0.2 \\
\hline \multicolumn{5}{|l|}{ Chemical composition } \\
\hline $\mathrm{NE}_{\mathrm{L}}{ }^{1}(\mathrm{MJ} / \mathrm{kg}$ of DM$)$ & 6.49 & 6.47 & 6.79 & 6.77 \\
\hline $\mathrm{CP}$ & 14.0 & 14.0 & 16.5 & 16.6 \\
\hline NDF & 38.4 & 38.2 & 35.6 & 35.5 \\
\hline $\mathrm{ADF}$ & 31.6 & 31.8 & 19.7 & 19.8 \\
\hline Crude fiber & 19.0 & 19.1 & 15.9 & 16.0 \\
\hline
\end{tabular}

${ }^{1}$ Calculated values from the analyses of all feedstuffs according to GfE (2001). 
from one evening and the next morning milking and pooled for further analysis. Bronopol (2-bromo-2-nitropropane-1,3-diol) preservative treated milk samples were transported to the regional laboratory of the milk recording organization (Landeskontrollverband Rheinland-Pfalz-Saar e.V., Bad Kreuznach, Germany) for analyzing concentrations of fat, protein, lactose, and SCC via infrared analyzer (MilkoScan FT-6000, Foss Analytical A/S, Hillerød, Denmark; LKV RheinlandPfalz-Saar e.V., Bad Kreuznach, Germany). Energycorrected milk was calculated according to GfE (2001), and was adjusted to $4 \%$ fat and $3.4 \%$ protein.

Blood samples were taken at wk $1(\mathrm{~d} 7 \pm 2)$, wk 3 (d $21 \pm 2$ ), and wk 5 (d $35 \pm 2$ ) postpartum before feeding between 0730 and $0830 \mathrm{~h}$ and were centrifuged immediately. For this purpose, cows were separated after the morning milking. Blood from the vena caudalis was collected into tubes containing EDTA as an anticoagulant (S-Monovette, Sarstedt, Nümbrecht, Germany) and centrifuged to obtain plasma which was stored at $-20^{\circ} \mathrm{C}$ until analysis.

In addition, liver biopsies were taken after sampling of blood at wk 1 (d $7 \pm 2$ ) and wk $3(\mathrm{~d} 21 \pm 2$ ) postpartum. Therefore, the relevant cow was separated after morning milking and its head was fixed in a locking yoke. After shaving and disinfecting of the liver biopsy site on the right side of the cow between the 11th and 12 th rib on a line between the olecranon and the tuber coxae, a local subcutaneous anesthesia with $5 \mathrm{~mL}$ of Isocaine 2\% (Procainhydrochloride/Epinephrin, Selectavet, Weyarn/Holzolling, Germany) was administered. A small incision was made with a scalpel (carbon steel scalpel blades \#11, Aesculap AG, Tuttlingen, Germany), and biopsies were taken with a sterile 14-G biopsy needle (Dispomed Witt oHG, Gelnhausen, Germany). Approximately $50 \mathrm{mg}$ of liver tissue was immediately snap-frozen in liquid nitrogen and stored at $-80^{\circ} \mathrm{C}$ until further analysis. After the biopsy, the puncture site was treated with antiseptic spray (Oxytetracycline spray blue, Bayer Health Care AG, Leverkusen, Germany).

\section{Analysis of Plasma and Liver Samples}

Concentrations of retinol, tocopherols, and $\beta$-carotene in plasma samples were determined by HPLC (L-7100, LaChrom, Merck-Hitachi, Darmstadt, Germany) according to Balz et al. (1993). Samples of $0.2 \mathrm{~mL}$ of plasma were mixed with $2 \mathrm{~mL}$ of a $10 \mathrm{~g} / \mathrm{L}$ of pyrogallol solution (in ethanol, absolute) and $300 \mu \mathrm{L}$ of a saturated sodium hydroxide solution. After flushing with nitrogen, this mixture was heated for $30 \mathrm{~min}$ at $70^{\circ} \mathrm{C}$ in closed glass tubes. The vitamins were then extracted by addition of $2 \mathrm{~mL}$ of n-hexane and $2 \mathrm{~mL}$ of distilled water. After centrifugation, an aliquot of the hexane phase was evaporated to dryness under nitrogen and re-dissolved in methanol containing $0.05 \%$ of butylated hydroxytoluene. Retinol and tocopherols were separated isocratically by HPLC using a mixture of methanol and water $(96: 4, \mathrm{vol} / \mathrm{vol})$ as the mobile phase and a LiChrospher 100 RP18 column (5 $\mu$ m particle size, 125 $\mathrm{mm}$ length, $4.6 \mathrm{~mm}$ internal diameter, Merck-Hitachi) and detected by fluorescence (Fluorescence Detector L-7480, Merck-Hitachi; retinol: excitation wavelength, $325 \mathrm{~nm}$; emission wavelength, $475 \mathrm{~nm}$; tocopherols: excitation wavelength, $295 \mathrm{~nm}$; emission wavelength, $325 \mathrm{~nm})$. For measurement of $\beta$-carotene, an aliquot of the hexane phase was directly injected on a LiChrospher 100 Diol column (5 $\mathrm{m}$ particle size, $125 \mathrm{~mm}$ length, $4.6 \mathrm{~mm}$ internal diameter, Merck-Hitachi) with hexane as the mobile phase and detected by absorption (UV-VIS-Detector L4250, Merck-Hitachi, absorption wavelength $455 \mathrm{~nm}$ ). The temperature of the columns was set at $40^{\circ} \mathrm{C}$ for the determination of retinol and tocopherols and $30^{\circ} \mathrm{C}$ for $\beta$-carotene using a column oven (L-7360, Merck-Hitachi). The vitamins were calculated by an external calibration based on linear regression. Following analytical standards were used: retinol (Sigma-R7632, Sigma-Aldrich, Taufkirchen, Germany); DL-all-rac- $\alpha$-tocopherol (Supelco-47783, SigmaAldrich), $\gamma$-tocopherol (Supelco-4778, Sigma-Aldrich), and $\beta$-carotene (Sigma-22040, Sigma-Aldrich). All the vitamins and $\beta$-carotene showed good linearity, with a correlation coefficient over 0.999. Instrumental precision and stability were determined by analyzing the same sample and standards a second time at the end, whereas the repeatability or precision of the method was obtained by processing one sample 5 times and calculating the variation. The stability for the standards and samples were between 95 and $102 \%$ per day and the sample pretreatment showed acceptable variations with 4 to $5 \%$ for all vitamins and $\beta$-carotene.

Thiobarbituric acid-reactive substances (TBARS) in plasma were measured using a modified version of the method of Sidwell et al. (1954). Sample aliquots were mixed with thiobarbituric acid reagent [thiobarbituric acid (8 g/L)/perchloric acid (70 g/L), 2:1 (vol/ vol)] and heated for $60 \mathrm{~min}$ at $95^{\circ} \mathrm{C}$. The TBARS were extracted with $n$-butanol and measured by fluorescence (excitation wavelength, $532 \mathrm{~nm}$; emission wavelength, $553 \mathrm{~nm}$; Fluorescence Spectrometer LS55, PerkinElmer, Rodgau, Germany). Concentrations were calculated via a standard curve with 1,1,3,3-tetraethoxypropane.

To determine TAG and cholesterol concentrations in the liver, lipids from liver biopsy samples were extracted with a mixture of n-hexane and isopropanol (3:2, vol/vol; Hara and Radin, 1978). Aliquots of the lipid extracts were concentrated under a nitrogen atmosphere at $37^{\circ} \mathrm{C}$ for $5 \mathrm{~min}$ (Techne sample concentra- 
tor, Bibby Scientific, Staffordshire, United Kingdom). The lipids were then dissolved using a 1:1-mixture of chloroform and Triton X-100 (De Hoff et al., 1978). After vacuum drying at $42^{\circ} \mathrm{C}$ for $2 \mathrm{~h}$, liver TAG and cholesterol content were measured using enzymatic reagent kits [Fluitest CHOL (Cat. No. 4241), Fluitest TG (Cat. No. 5741), Analyticon Biotechnologies AG, Lichtenfels, Germany], respectively.

The Trolox equivalent antioxidant capacity (TEAC) of plasma was determined following the protocol of Re et al. (1999). Oxidation of 2,29-azinobis-(3-ethylbenzothiazoline-6-sulfonic acid; ABTS) with potassium persulfate generates the blue/green radical mono cation $\left(\mathrm{ABTS}^{+}\right)$, which is reduced in the presence of hydrogen-donating antioxidants including hydrophilic and lipophilic antioxidants. Antioxidants contained in the sample reduce $\mathrm{ABTS}^{+} \bullet$ to ABTS and therefore cause decolorization proportional to their concentration. The absorbance was measured in a microplate-reader (Infinite M200, Tecan, Germany) at a wavelength of $600 \mathrm{~nm}$, and antioxidant capacity of the plasma was calculated against Trolox as a standard. The TEAC values expressed the millimoles of Trolox having the antioxidant capacity corresponding to $1.0 \mathrm{mmol}$ of the test substance (Betancor-Fernandez et al., 2002).

Concentrations of NEFA and BHBA in plasma samples were analyzed using enzymatic reagent kits (Code No. 436-396-91995 and 417-73501, Wako Chemicals GmbH, Neuss, Germany).

\section{Quantitative PCR}

Total RNA isolation from liver biopsies, cDNA synthesis, and quantitative(q)PCR were performed as described recently in detail (Gessner et al., 2013a). Expression values of the examined genes were normalized using the GeNorm normalization factor according to Vandesompele et al. (2002) with $A C T B$ (forward 5'-ACTTGCGCAGAAAACGAGAT-3' and reverse 5'-CACCTTCACCGTTCCAGTTT-3'), ATP5B (forward 5'-GGACTCAGCCCTTCAGCGCC-3' and reverse $5^{\prime}$ - GCCTGGTCTCCCTGCCTTGC-3'), and SDHA (forward 5'- GCAGAACCTGATGCTTTGTG-3' and reverse 5'-CGTAGGAGAGCGTGTGCTT-3'), being the 3 most stable out of 6 tested potential reference genes in the liver. Details about gene-specific primer pairs for the target genes catalase $(C A T)$, C-reactive protein $(C R P)$, glutathione peroxidase 3 (GPX3), haptoglobin $(H P)$, microsomal glutathione S-transferase 3 (MGST3), $\mathrm{NAD}(\mathrm{P}) \mathrm{H}$ dehydrogenase, quinone 1 (NQO1), superoxide dismutase 1 (SOD1), tumor necrosis factor $\alpha(T N F)$, UDP glucuronosyltransferase 1 family, polypeptide A1 (UGT1A1), and activating transcription factor 4 (ATF4), BCL2-antagonist/killer
1 (BAK1), BCL2-associated $\mathrm{X}$ protein $(B A X)$, heat shock $70 \mathrm{kDa}$ protein 5 (HSPA5), apoptosis-related cysteine peptidase 3 (CASP3), DNA-damage-inducible transcript 3 (DDIT3), ER degradation enhancer, mannosidase $\alpha$-like (EDEM1), protein disulfide isomerase family A, member 4 (PDIA4), X-box binding protein 1 (XBP1) can be obtained from recent publications (Gessner et al., 2013a, 2014). The following primer pair was used for the detection of mRNA abundancy of fibroblast growth factor 21 (FGF21): forward 5'-GGCATCATCCGTGTAGAGGT-3' and reverse $5^{\prime}$-TTCAAGCACTTGGGACTGTG- $3^{\prime}$ ). The mean of wk 1 postpartum was set to 1 , and relative expression ratios of wk 3 and the average of wk 1 and 3 are expressed as fold changes compared with wk 1 postpartum. The size of the PCR products were verified using $1.5 \%$ agarose gel electrophoresis, stained with GelRed nucleic acid gel stain (Biotium, Hayward, CA), and visualized under UV light with a digital camera (SynGene, Cambridge, United Kingdom).

\section{Statistics}

Data were analyzed with a linear mixed-effects model using packages lmerTest (Kuznetsova et al., 2014) and lsmeans (Lenth and Hervé, 2013) in R version 3.1.1 ( $\mathrm{R}$ Core Team 2014). The linear mixed-effects model included treatment, week, lactation number $(1,2-3$, or $\geq 4$ ), and the treatment $\times$ week interaction as fixed factors and cow as a random factor to account for repeated measures over the weeks on the same animal. Pairwise comparisons between the overall treatment means and means at each sampling time point were performed using linear contrasts for least squares means. Differences at $P<0.05$ were considered as statistically significant, and differences at $P<0.1$ were considered as trends.

\section{RESULTS}

No significant difference in the deviation of actual from expected calving dates occurred between the control group and the GSGME group $(1.1 \pm 3.2$ versus $-1.7 \pm 4.3$, respectively). Actual calving dates ranged from $7 \mathrm{~d}$ before to $7 \mathrm{~d}$ after the expected calving date.

\section{Feed Intake, Energy Balance, Milk Production, and Composition}

No visual indications were present for sorting behavior of the cows. Thus, it can be assumed that the cows of the GSGME group consumed the proposed amount of GSGME. Feed intake, milk production, and composition were determined weekly in the period of wk 2 to 9 postpartum. As expected, feed and energy intake, 
energy balance, milk yield, and milk composition were influenced by week of lactation $(P<0.05$, Table 2$)$. However, no interactions between treatment and time were observed (Table 2). Cows of the GSGME group did not differ in $\mathrm{DMI}, \mathrm{NE}_{\mathrm{L}}$ intake, and energy balance from cows of the control group in the time period of wk 2 to 9 postpartum (Table 2). However, milk yield and ECM were higher in the GSGME group than in the control group $(P<0.05$, Table 2$)$. Milk composition (concentrations of fat, protein, and lactose) was not different between both groups of cows (Table 2). The daily amount of milk protein was higher in the GSGME group than in the control $(P=0.028)$; the daily amount of fat did not differ between the 2 groups of cows (Table 2 ). The time course of DMI, milk yield, and ECM is shown in Figure 1. The DMI was not different between the 2 groups of cows at any time point (Figure 1A). Milk yield was significantly higher $(P<0.05)$ from the cows supplemented with GSGME at wk 4,5 , and 6 and tended to be increased $(P<0.10)$ in wk 3 and 7 in comparison with the control group (Figure 1B). The ECM was significantly increased in the cows supplemented with GSGME in wk 4, 5, 7, and 9 in comparison with the control cows $(P<0.05$, Figure $1 \mathrm{C})$.

\section{Metabolic and Antioxidant Parameters in Plasma}

Concentration of various metabolic and antioxidant parameters in plasma are shown in Table 3. All these parameters were determined in wk 1,3 , and 5 postpartum. Most of the parameters considered were influenced by week of lactation. The TAG, retinol, TBARS, TEAC, $\alpha$-tocopherol, and $\beta$-carotene concentrations were lowest during wk 1 and were thereafter increasing (Table 2). Plasma NEFA concentration was highest during wk 1 and was thereafter decreasing (Table 2). Plasma BHBA concentration was not different in the time interval between wk 1 and 5 (Table 2). No interactions were found between treatment and time for all parameters considered, indicating that effects of the treatment (GSGME vs. control) were independent of week of lactation. Cows of the GSGME group had higher concentrations of BHBA and retinol in plasma than cows of the control group $(P<0.05$, Table 3$)$. In contrast, concentrations of NEFA, TAG, and all the parameters related to the antioxidant system ( $\alpha$-tocopherol, $\beta$-carotene, TEAC, and TBARS) determined in plasma samples did not differ between the 2 groups of cows (Table 3).

\section{Liver TAG and Cholesterol Concentrations}

Concentrations of TAG and cholesterol in the liver, determined in samples of wk 1 and 3, did not differ between GSGME group and the control group (Table 4).

\section{mRNA Abundances of Genes of UPR, Nrf2 Pathway, and Inflammation in the Liver}

The mRNA abundances of inflammatory genes, genes of the UPR, and genes of the Nrf2 pathway in liver biopsy samples were determined at 1 to 3 wk postpartum. The mRNA abundances of most of the genes considered were influenced by week of lactation (Table 4). The mRNA abundances of the majority of the genes considered (ATF4, BAK1, EDEM1, PDIA4, CAT, NQO1, $S O D 1, U G T 1 A 1, C R P)$ were higher at wk 3 than at wk $1(P<0.05)$; mRNA abundances of fewer genes $(B A X$, DDIT3, GPX3) were lower at wk 3 than at wk $1(P$ $<0.05)$. The mRNA abundances of CASP3, FGF21, HSPA 5, XBP1, MGST3, HP, and TNF did not differ between wh 1 and 3 (Table 4). No interactions were found between time and treatment for mRNA abundances of all the genes considered (Table 4). Hepatic

Table 2. Feed intake, milk production, and milk composition of Holstein cows fed the control diet or the diet supplemented with $1 \%$ of grape seed and grape marc meal extract (GSGME) on average over wk 2 to 9 of lactation ${ }^{1}$

\begin{tabular}{|c|c|c|c|c|c|c|}
\hline Variable & \multicolumn{2}{|c|}{ Wk 2 to 9} & SEM & \multicolumn{3}{|c|}{$P$-value } \\
\hline DMI $(\mathrm{kg} / \mathrm{d})$ & 16.6 & 17.2 & 0.63 & 0.515 & $<0.001$ & 0.629 \\
\hline Energy balance (MJ $\mathrm{NE}_{\mathrm{L}} / \mathrm{d}$ ) & -29.9 & -36.5 & 5.40 & 0.390 & $<0.001$ & 0.631 \\
\hline Milk yield $(\mathrm{kg} / \mathrm{d})$ & 35.4 & 39.0 & 1.06 & 0.029 & $<0.001$ & 0.678 \\
\hline $\operatorname{ECM}^{2}(\mathrm{~kg} / \mathrm{d})$ & 33.9 & 37.0 & 1.04 & 0.045 & 0.076 & 0.312 \\
\hline Lactose (\%) & 4.80 & 4.83 & 0.03 & 0.470 & $<0.001$ & 0.931 \\
\hline Fat $(\mathrm{kg} / \mathrm{d})$ & 1.37 & 1.47 & 0.05 & 0.142 & 0.884 & 0.478 \\
\hline Protein (kg/d) & 1.09 & 1.21 & 0.04 & 0.028 & 0.887 & 0.328 \\
\hline
\end{tabular}

${ }^{1}$ Values are least squares means, $\mathrm{n}=14$ for each group.

${ }^{2} \mathrm{ECM}$, adjusted to $4 \%$ fat and $3.4 \%$ protein. 
A
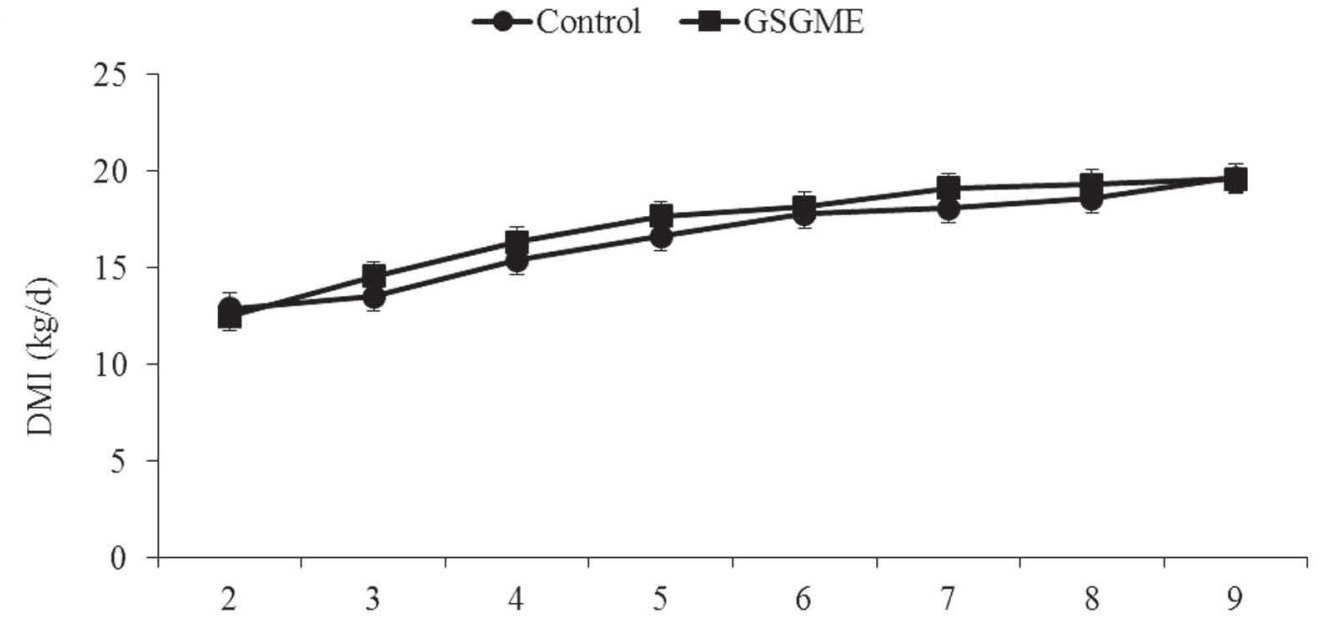

B

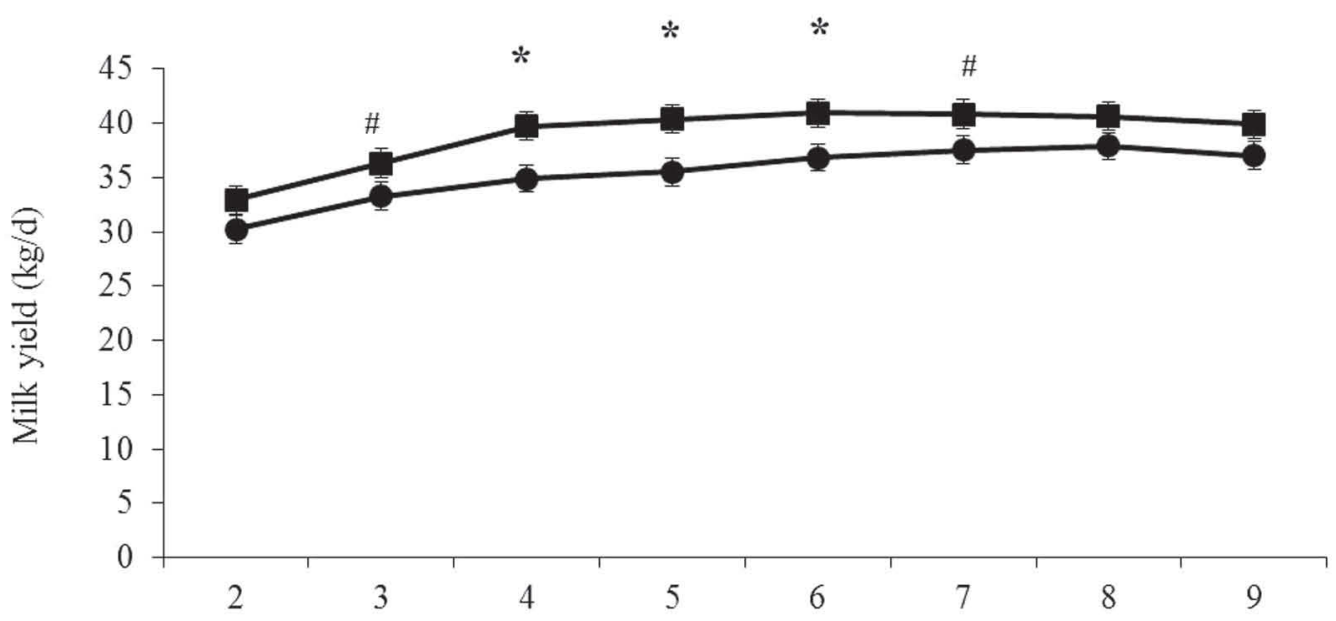

$\mathrm{C}$

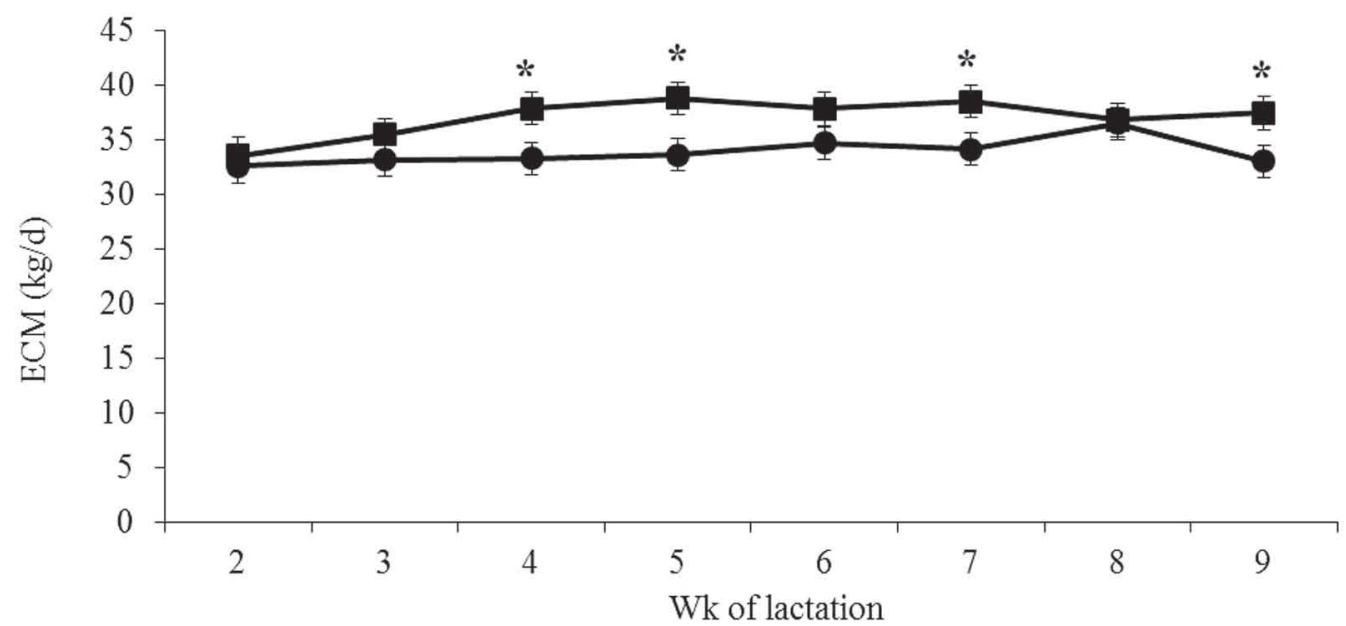

Figure 1. Dry matter intake (A), milk yield (B), and ECM (C) in control cows and cows supplemented with grape seed and grape marc meal extract (GSGME) in the period from wk 2 to 9 of lactation. Values are least squares means \pm standard errors; control, $\mathrm{n}=14$ for each group. Symbols indicate difference from control group $\left({ }^{*} P<0.05 ; \# P<0.10\right)$. 
mRNA abundancy of FGF21 was significantly reduced in the GSGME group in wk 1 and 3 in comparison with the control group $(P=0.034$, Table 4$)$. The mRNA abundances of all the other genes considered in wk 1 and 3 did not differ between the 2 groups of cows (Table 4). However, trends were observed toward a reduction of the mRNA abundances of XBP1 and UGT1A1 in the cows supplemented with GSGME at wk 1 and $3(P<$ 0.10 , Table 4).

\section{DISCUSSION}

The aim of this study was to investigate the hypothesis that feeding GSGME, a by-product of wine and grape juice processing rich in flavonoids, is able to attenuate inflammation and ER stress in the liver of dairy cows. Considering that most studies dealing with the effects of flavonoids have been performed with monogastric animals, less is known about potential degradation or chemical modification of flavonoids by the microbial flora in the rumen. However, one study performed with sheep shows that the bioavailability of proanthocyanidins from plant extracts is even increased in ruminants in comparison with monogastric animals due to hydrolyzation of polymeric compounds into bioactive monomers by the microbial flora (Gladine et al., 2007). That study also documented the recovery of flavonoids from diet sources in plasma, indicating that at least a part of the flavonoids has been absorbed in the intestine. According to that study, it is expected that at least a part of the flavonoids of GSGME used in the present study is bioavailable and could exert biological effects in the body of cows.

To investigate the effect of GSGME on the inflammatory condition and the occurrence of ER stress in the liver, we considered mRNA abundances of relevant genes in liver samples collected in wk 1 and 3 of lactation. These time points were selected because our previous studies have shown that both inflammation and ER stress reach their maximum in the time interval between wk 1 and 5 of lactation (Gessner et al., 2013a, 2014). We found that mRNA abundances of $T N F$, a pro-inflammatory cytokine, as well as $H P$ and $C R P, 2$ acute phase proteins, in the liver were not different between the 2 groups of cows at wk 1 and 3 . This finding indicates that supplementation of GSGME did not influence the inflammation process in the liver of cows. We moreover observed that supplementation of GSGME caused a trend toward a downregulation of 2 genes involved in the UPR (XBP1, UGT1A1). However, mRNA abundances of the majority of hepatic genes involved in UPR such as HSPA5, a chaperone which functions as the master regulator of the UPR (Cnop et al., 2012), several downstream genes of the 
3 ER stress transducers, including ER chaperones, ER-associated protein degradation components (Ron and Walter, 2007; Samali et al., 2010), genes involved in the induction of apoptosis (Wu et al., 2013), and genes of the Nrf2 pathway that are driven by ER stress (Cullinan et al., 2003) remained completely unchanged between both groups of cows. These findings indicate that supplementation of GSGME had less effect on the development of ER stress in the liver of dairy cows in the early postpartal phase.

So far, the effects of plant flavonoids on inflammation and ER stress have been less investigated in ruminants. However, one study is available showing that GS extract is able to reduce the production of pro-inflammatory cytokines and heat shock protein 70, a target gene of the UPR, in heat-stressed jejunum epithelial cells of steers ( $\mathrm{Li}$ et al., 2014). The results of that study show that plant flavonoids are generally able to attenuate inflammation and ER stress in bovine cells. Three reasons are possible for the finding that supplementation of GSGME failed to attenuate inflammation and ER stress in the liver of dairy cows in this study. First, the basal level of inflammation and ER stress in the liver could have been generally too low to observe potential beneficial effects of GSGME. Second, a large part of the flavonoids could have been degraded in the rumen. Third, concentrations of flavonoids supplied by GSGME could have been insufficient to induce anti-inflammatory effects in the liver.

One interesting finding of this study is that supplementation of GSGME caused a significant downregulation of FGF21 in the liver at wk 1 and 3 of lactation. The FGF21 was originally identified as an important metabolic hormone that controls fatty acid oxidation and ketogenesis during fasting (Inagaki et al., 2007). Recent studies, however, have shown that FGF21 also

Table 4. Concentrations of lipids and hepatic mRNA abundances of genes of the unfolded protein response, Nrf2 target genes, and genes involved in inflammation in the liver of Holstein cows fed the control diet or the diet supplemented with $1 \%$ of grape seed and grape marc meal extract (GSGME) at wh 1 and $3^{1}$

\begin{tabular}{|c|c|c|c|c|c|c|c|c|}
\hline \multirow[b]{2}{*}{ Item } & \multicolumn{2}{|c|}{ Wk 1} & \multicolumn{2}{|c|}{ Wk 3} & \multirow[b]{2}{*}{ SEM } & \multicolumn{3}{|c|}{$P$-value } \\
\hline & Control & GSGME & Control & GSGME & & GSGME & Time & GSGME $\times$ time \\
\hline \multicolumn{9}{|c|}{ Lipid concentration $(\mu \mathrm{mol} / \mathrm{g})$} \\
\hline TAG & 68.9 & 49.3 & 81.0 & 40.7 & 12.6 & 0.109 & 0.884 & 0.363 \\
\hline Cholesterol & 11.8 & 10.1 & 10.2 & 7.91 & 0.83 & 0.106 & 0.027 & 0.714 \\
\hline \multicolumn{9}{|c|}{ Gene expression ${ }^{2,3}$} \\
\hline \multicolumn{9}{|c|}{ Unfolded protein response } \\
\hline$A T F 4$ & 1.00 & 0.70 & 1.40 & 1.14 & 0.19 & 0.292 & 0.048 & 0.900 \\
\hline$B A K 1$ & 1.00 & 0.72 & 1.53 & 1.25 & 0.29 & 0.497 & 0.001 & 0.998 \\
\hline$B A X$ & 1.00 & 0.35 & 0.32 & 0.24 & 0.10 & 0.265 & 0.002 & 0.653 \\
\hline$C A S P 3$ & 1.00 & 0.75 & 0.90 & 0.98 & 0.15 & 0.670 & 0.652 & 0.279 \\
\hline DDIT3 & 1.00 & 0.69 & 0.63 & 0.53 & 0.09 & 0.110 & 0.005 & 0.222 \\
\hline$E D E M 1$ & 1.00 & 0.62 & 2.76 & 2.31 & 0.40 & 0.518 & 0.004 & 0.980 \\
\hline$F G F 21$ & 1.00 & 0.55 & 1.19 & 0.29 & 0.22 & 0.034 & 0.888 & 0.333 \\
\hline HSPA5 & 1.00 & 0.38 & 1.13 & 0.75 & 0.22 & 0.126 & 0.102 & 0.396 \\
\hline $\mathrm{PDIA}_{4}$ & 1.00 & 0.43 & 1.19 & 1.16 & 0.20 & 0.281 & 0.009 & 0.076 \\
\hline$X B P 1$ & 1.00 & 0.41 & 0.90 & 0.67 & 0.15 & 0.073 & 0.391 & 0.071 \\
\hline \multicolumn{9}{|c|}{ Nrf2 pathway } \\
\hline$C A T$ & 1.00 & 0.71 & 1.82 & 1.17 & 0.27 & 0.233 & 0.014 & 0.428 \\
\hline$G P X 3$ & 1.00 & 2.30 & 0.40 & 0.38 & 0.34 & 0.192 & 0.009 & 0.132 \\
\hline MGST3 & 1.00 & 0.70 & 1.47 & 0.96 & 0.24 & 0.243 & 0.052 & 0.535 \\
\hline NQO1 & 1.00 & 0.97 & 5.57 & 4.03 & 0.79 & 0.478 & 0.001 & 0.485 \\
\hline$S O D 1$ & 1.00 & 0.82 & 2.69 & 2.24 & 0.47 & 0.627 & 0.015 & 0.810 \\
\hline$U G T 1 A 1$ & 1.00 & 0.45 & 1.48 & 0.84 & 0.24 & 0.098 & 0.038 & 0.800 \\
\hline \multicolumn{9}{|c|}{ Inflammation } \\
\hline$C R P$ & 1.00 & 0.52 & 1.67 & 1.56 & 0.28 & 0.433 & 0.008 & 0.427 \\
\hline$H P$ & 1.00 & 0.35 & 0.32 & 0.24 & 0.21 & 0.237 & 0.070 & 0.176 \\
\hline$T N F$ & 1.00 & 0.49 & 1.18 & 1.01 & 0.20 & 0.455 & 0.217 & 0.536 \\
\hline
\end{tabular}

${ }^{1}$ Values are least squares means, $\mathrm{n}=14$ for each group. The mRNA abundances of genes are expressed relative to the mRNA concentration at 1 wk postpartum $(=1.00)$.

${ }^{2}$ Values are least squares means, $\mathrm{n}=14$ for each group.

${ }^{3} A T F 4=$ activating transcription factor $4 ; B A K 1=$ BCL2-antagonist/killer $1 ; B A X=$ BCL2-associated $\mathrm{X}$ protein; $C A S P=$ apoptosis-related cysteine peptidase; $C A T=$ catalase; $C R P=$ C-reactive protein; DDIT3 = DNA-damage-inducible transcript 3 ; EDEM1 $=$ ER degradation enhancer, mannosidase $\alpha$-like; FGF21 = fibroblast growth factor 21; GPX3 = glutathione peroxidase $3 ; H S P A 5=$ heat shock $70 \mathrm{kDa}$ protein 5; MGST3 = microsomal glutathione S-transferase $3 ; H P=$ haptoglobin; $H M O X 2=$ heme oxygenase $2 ; N Q O 1=\mathrm{NAD}(\mathrm{P}) \mathrm{H}$ dehydrogenase, quinone $1 ; P D I A 4=$ protein disulfide isomerase family $\mathrm{A}$, member $4 ; S O D 1=$ superoxide dismutase $1 ; T N F=$ tumor necrosis factor; $U G T 1 A 1$ $=\mathrm{UDP}$ glucuronosyltransferase 1 family, polypeptide A1; XBP1 = X-box binding protein 1. 
acts as a stress hormone that is directly induced by ER stress, but also by several other stress conditions such as starvation, nutrient excess, autophagy deficiency, mitochondrial stress, exercise, or cold exposure (Kim and Lee, 2014). It has been observed that FGF21 in the liver of dairy cows is dramatically upregulated during the transition from late pregnancy to early lactation (Carriquiry et al., 2009; Schoenberg et al., 2011; Schlegel et al., 2012), probably as a consequence of various types of stress present in the liver during the periparturient phase. Thus, the finding of a reduced mRNA abundancy of FGF21 suggests that supplementation of GSGME lowered the generation of stress in the liver during early lactation. This suggestion is in accordance with the observation of an increased plasma retinol concentration observed in the cows supplemented with GSGME. Retinol is released from the liver after binding to retinol-binding protein, a member of the negative acute phase proteins (Bossaert et al., 2012). It has been shown that plasma retinol concentrations are reduced under stress conditions or inflammation, due to a reduced synthesis of retinol-binding protein (Bionaz et al., 2007; Bossaert et al., 2012). Thus, an increased plasma concentration of retinol could be further indication that the level of stress could have been reduced in the liver by supplementation of GSGME.

In the present study, we observed an unexpected increase of milk production, associated with an increased daily milk protein yield, in the cows fed GSGME in comparison with the control group. As DMI was similar in both groups, it is likely that the utilization of energy and crude protein from diet for milk production might have been improved in the cows supplemented with GSGME in comparison with the control cows. As GSGME had less effect on inflammation and ER stress, it is likely that the effects on milk production might have been due to an improved rumen fermentation than rather an altered metabolism. In vitro and in vivo studies have shown that grape products influence ruminal fermentation (Moate et al., 2014; Ishida et al., 2015; Khiaosa-Ard et al., 2015). Grape products are characterized by high concentrations of tannins, which might be most relevant for their influence on ruminal metabolism (Khiaosa-Ard et al., 2015). Tannins are able to form complexes with proteins, leading to a decrease in protein solubility and degradation in the rumen and an increased dietary protein flow to the duodenum (Patra and Saxena, 2011). High dietary levels of tannins can compromise feed intake and digestion in feeds (Patra and Saxena, 2011). However, feeding moderate levels of tannins, which do not affect feed intake, has been shown to improve milk yield, likely due to an increased flux of EAA to the small intestine (Woodward et al.,
1999; Bhatta et al., 2000). Recently, feeding a relatively large amount of dried GM $(5.0 \mathrm{~kg} / \mathrm{d})$ to dairy cows in late lactation slightly increased the milk yield and daily amount of milk protein in comparison with a control group (Moate et al., 2014). In another recent study, feeding polyphenol-rich winery wastes lowered microbial protein degradation in wethers (Ishida et al., 2015). These findings are in accordance with the view that tannins from grape products could increase milk yield by increasing the flux of protein to the small intestine (Moate et al., 2014). Besides their effects on protein degradation in the rumen, tannins from grape products are also able to reduce methanogenesis (Patra and Saxena, 2011). According to an in vitro study, this effect might be mainly due to a change of the microbial population, associated with a moderate depression of nonfiber carbohydrate degradation (Khiaosa-Ard et al., 2015). In contrast, grape products had less effect on the production of individual VFA, both in vitro and in vivo (Moate et al., 2014; Khiaosa-Ard et al., 2015). Based on these studies, the alterations observed in the cows supplemented with GSGME in this study (increased milk yield, increased daily milk protein yield) could be due to a reduced ruminal degradation of crude protein from the diet, leading to an increased amount of protein available in the small intestine. However, as we did not investigate ruminal metabolism in this study, this suggestion remains a matter of speculation. The results of our study with respect to the effect of GSGME feeding on milk yield are, however, contrary to some other studies that investigated the effect of feeding grape products in lactating ruminants. In the study of Santos et al. (2014), inclusion of grape residue silage in amounts up to $10 \%$ of food DM decreased total-tract apparent digestibility of DM, CP, ether extract, and fiber fractions in Holstein cows but did not influence milk yield and milk composition. In the study of Nudda et al. (2015), feeding $300 \mathrm{~g} / \mathrm{d}$ per head of GS did not influence milk yield and milk composition and had less effect on hematological and metabolic parameters in dairy ewes. Both studies indicate that grape products can be included into lactating ruminant diets without adverse effects on milk production. A study in nonlactating multiparous cows showed that feeding of GM in amounts of up to $3 \mathrm{~kg}$ of DM per day lowers $\mathrm{N}$ digestibility and $\mathrm{N}$ excretion in feces (Greenwood et al., 2012). The authors of that study suggested that this effect may be particularly beneficially when feeding diets high in rumen-degradable protein such as in a ryegrass-clover pasture by creating a partitioning of $\mathrm{N}$ toward feces instead of absorption.

Plasma NEFA and BHBA are important metabolic parameters in dairy cows during early lactation. Non- 
esterified fatty acids originate from adipose tissue, and their concentration in plasma mainly reflects mobilization of body fat. However, plasma NEFA concentration can also be modified by their uptake into tissues by FA transporters (Jorritsma et al., 2003). The finding that plasma NEFA concentration was not influenced by feeding GSGME is in accordance with the observation of a similar energy balance in both groups of cows, and moreover suggests that there might not have been a profound difference in the uptake of NEFA into tissue by FA transporters between the 2 groups of cows. Plasma BHBA concentration in cows during early lactation is an indicator of hepatic ketogenesis. We found that cows supplemented with GSGME had increased plasma concentrations of BHBA in wk 1,3 , and 5 compared with the control group. It is well known that the rate of ketogenesis is dependent on the availability of glucose (van Knegsel et al., 2005). Accordingly, it is likely that the increase in BHBA was due to a lower availability of glucose due to increased lactose synthesis in the GSGME group, which produced 3 to $4 \mathrm{~kg}$ more milk than the control group at a similar DMI.

Until recently, few studies dealing with the effects of flavonoids in ruminants have been published. Some of those studies revealed that flavonoids, due to their high antioxidative potential, are able to increase the antioxidative status and reduce lipid peroxidation in plasma of sheep (Gladine et al., 2007), dairy cows (Gobert et al., 2009), or beef cattle (Shabtay et al., 2008). These studies suggested that feeding flavonoid-rich plant extracts could be a strategy to improve health and performance of ruminants by reducing oxidative stress. Our study, demonstrating that feeding of GSGME does not increase the antioxidative capacity and does not reduce the lipid peroxidation in plasma of cows, is in contrast to those studies. Differences in the effects of flavonoids on the antioxidant system between our study and other studies could be at least in part due to different plant sources used in these studies.

\section{CONCLUSIONS}

The data of this study indicate that supplementation of dairy cows with GSGME from wk 3 prepartum to wk 9 increased milk production but had no significant effects on inflammation and the occurrence of ER stress in the liver of dairy cows during early lactation. The finding that hepatic mRNA abundancy of FGF21, a stress hormone induced by various types of stress, was reduced in the cows supplemented with GSGME suggests an attenuation of stress in the liver of these cows. Consideration of various antioxidative parameters and concentrations of lipid peroxidation products (TBARS) in plasma indicates that supplementation of GSGME did not influence the systemic antioxidative system. Overall, the data of this study indicate that a moderate amount of GSGME could be useful to improve milk performance in dairy cows without negatively affecting energy balance. As less effect of the supplement on metabolism was observed, it is likely that the increased milk performance could be mainly due to effects of GSGME on ruminal metabolism.

\section{REFERENCES}

Auger, C., P. Gerain, F. Laurent-Bichon, K. Portet, A. Bornet, B. Caporiccio, G. Cros, P. L. Teissedre, and J. M. Rouanet. 2004 Phenolics from commercialized grape extracts prevent early atherosclerotic lesions in hamsters by mechanisms other than antioxidant effect. J. Agric. Food Chem. 52:5297-5302.

Balz, M. K., E. Schulte, and H. P. Their. 1993. Simultaneous determination of tocopheryl acetate, tocopherols and tocotrienols by HPLC with fluorescence detection in foods. Fat Sci Technol 95:215-220.

Betancor-Fernandez, A., H. Sies, W. Stahl, and M. C. Polidori 2002. In vitro antioxidant activity of 2,5,7,8-tetramethyl-2-(2'carboxyethyl)-6-hydroxychroman (alpha-CEHC), a vitamin E metabolite. Free Radic. Res. 36:915-921.

Bharrhan, S., K. Chopra, S. K. Arora, J. S. Toor, and P. Rishi. 2012 Down-regulation of NF-kappaB signalling by polyphenolic compounds prevents endotoxin-induced liver injury in a rat model. Innate Immun. 18:70-79.

Bhatta, R., U. Krishnamurty, and F. Mohammed. 2000. Effect of feeding tamarind (Tamarindus indiuca) seed husk as a source of tannin on dry matter intake, digestibility of nutrients and production performance of cross-bred dairy cows in mid lactation. Anim. Feed Sci. Technol. 83:67-74

Bionaz, M., E. Trevisi, L. Calamari, F. Librandi, A. Ferrari, and G. Bertoni. 2007. Plasma paraoxonase, health, inflammatory conditions, and liver function in transition dairy cows. J. Dairy Sci. 90:1740-1750.

Bonilla, F., M. Mayen, J. Merida, and M. Medina. 1999. Extraction of phenolic compounds from red grape marc for use as food lipid antioxidants. Food Chem. 66:209-215.

Bossaert, P., E. Trevisi, G. Opsomer, G. Bertoni, S. De Vliegher, and J. L. Leroy. 2012. The association between indicators of inflammation and liver variables during the transition period in highyielding dairy cows: An observational study. Vet. J. 192:222-225.

Bradford, B. J., K. Yuan, J. K. Farney, L. K. Mamedova, and J. A. Carpenter. 2015. Invited review: Inflammation during the transition to lactation: New adventures with an old flame. J. Dairy Sci. 98: http://dx.doi.org/10.3168/jds.2015-9683.

Carriquiry, M., W. J. Weber, S. C. Fahrenkrug, and B. A. Crooker. 2009. Hepatic gene expression in multiparous Holstein cows treated with bovine somatotropin and fed n-3 fatty acids in early lactation. J. Dairy Sci. 92:4889-4900.

Carroll, J. A., R. R. Reuter, C. C. Chase Jr., S. W. Coleman, D. G Riley, D. E. Spiers, J. D. Arthington, and M. L. Galyean. 2009. Profile of the bovine acute-phase response following an intravenous bolus-dose lipopolysaccharide challenge. Innate Immun. 15:81-89.

Cnop, M., F. Foufelle, and L. A. Velloso. 2012. Endoplasmic reticulum stress, obesity and diabetes. Trends Mol. Med. 18:59-68.

Cullinan, S. B., and J. A. Diehl. 2006. Coordination of ER and oxidative stress signaling: The PERK/Nrf2 signaling pathway. Int. J. Biochem. Cell Biol. 38:317-332.

Cullinan, S. B., D. Zhang, M. Hannink, E. Arvisais, R. J. Kaufman, and J. A. Diehl. 2003. Nrf2 is a direct PERK substrate and effector of PERK-dependent cell survival. Mol. Cell. Biol. 23:7198-7209. 
De Hoff, J. L., J. H. Davidson, and V. Kritchevsky. 1978. An enzymatic assay for determining free and total cholesterol in tissues. Clin. Chem. 24:433-435.

Drackley, J. K. 1999. Biology of dairy cows during the transition period: The final frontier? J. Dairy Sci. 82:2259-2273.

Drackley, J. K., T. R. Overton, and G. N. Douglas. 2001. Adaptations of glucose and long-chain fatty acid metabolism in liver of dairy cows during the periparturient period. J. Dairy Sci. 84:E100-E112.

Gentile, C. L., M. A. Frye, and M. J. Pagliassotti. 2011. Fatty acids and the endoplasmic reticulum in nonalcoholic fatty liver disease. Biofactors 37:8-16.

Gessner, D. K., A. Fiesel, E. Most, J. Dinges, G. Wen, R. Ringseis, and K. Eder. 2013a. Supplementation of a grape seed and grape marc meal extract decreases activities of the oxidative stress-responsive transcription factors NF-kappaB and Nrf2 in the duodenal mucosa of pigs. Acta Vet. Scand. 55:18.

Gessner, D. K., G. Schlegel, J. Keller, F. J. Schwarz, R. Ringseis, and K. Eder. 2013b. Expression of target genes of nuclear factor E2related factor 2 in the liver of dairy cows in the transition period and at different stages of lactation. J. Dairy Sci. 96:1038-1043.

Gessner, D. K., G. Schlegel, R. Ringseis, F. J. Schwarz, and K. Eder. 2014. Up-regulation of endoplasmic reticulum stress induced genes of the unfolded protein response in the liver of periparturient dairy cows. BMC Vet. Res. 10:46.

GfE (German Society of Nutrition Physiology). 2001. Empfehlungen zur Energie- und Nährstoffversorgung der Milchkühe und Aufzuchtrinder. DLG-Verlag, Frankfurt/Main, Germany.

Giordano, E., A. Davalos, N. Nicod, and F. Visioli. 2014. Hydroxytyrosol attenuates tunicamycin-induced endoplasmic reticulum stress in human hepatocarcinoma cells. Mol. Nutr. Food Res. 58:954-962.

Gladine, C., E. Rock, C. Morand, D. Bauchart, and D. Durand. 2007. Bioavailability and antioxidant capacity of plant extracts rich in polyphenols, given as a single acute dose, in sheep made highly susceptible to lipoperoxidation. Br. J. Nutr. 98:691-701.

Gobert, M., B. Martin, A. Ferlay, Y. Chilliard, B. Graulet, P. Pradel, D. Bauchart, and D. Durand. 2009. Plant polyphenols associated with vitamin $\mathrm{E}$ can reduce plasma lipoperoxidation in dairy cows given n-3 polyunsaturated fatty acids. J. Dairy Sci. 92:6095-6104.

Greenwood, S. L., G. R. Edwards, and R. Harrison. 2012. Short communication: Supplementing grape marc to cows fed a pasturebased diet as a method to alter nitrogern partitioning and excretion. J. Dairy Sci. 95:755-758.

Hara, A., and N. S. Radin. 1978. Lipid extraction of tissues with a low-toxicity solvent. Anal. Biochem. 90:420-426.

Heber, D., Y. Zhang, J. Yang, J. E. Ma, S. M. Henning, and Z. Li. 2014. Green tea, black tea, and oolong tea polyphenols reduce visceral fat and inflammation in mice fed high-fat, high-sucrose obesogenic diets. J. Nutr. 144:1385-1393.

Inagaki, T., P. Dutchak, G. Zhao, X. Ding, L. Gautron, V. Parameswara, Y. Li, R. Goetz, M. Mohammadi, V. Esser, J. K. Elmquist, R. D. Gerard, S. C. Burgess, R. E. Hammer, D. J. Mangelsdorf, and S. A. Kliewer. 2007. Endocrine regulation of the fasting response by PPARalpha-mediated induction of fibroblast growth factor 21 . Cell Metab. 5:415-425.

Ishida, K., Y. Kishi, K. Oishi, H. Hirooka, and H. Kumagai. 2015. Effects of feeding polyphenol-rich winery wastes on digestibility, nitrogen utilization, ruminal fermentation, antioxidant status and oxidative stress in wethers. Anim. Sci. J. 86:260-269.

Jorritsma, R., T. Wensing, T. A. Kruip, P. L. Vos, and J. P. Noordhuizen. 2003. Metabolic changes in early lactation and impaired reproductive performance in dairy cows. Vet. Res. 34:11-26.

Khiaosa-Ard, R., B. U. Metzler-Zebeli, S. Ahmed, A. Muro-Reyes, K. Deckardt, R. Chizzola, J. Böhm, and Q. Zebeli. 2015. Fortification of dried distillers grains plus solubles with grape seed meal in the diet modulates methane mitigation and rumen microbiota in Rusitec. J. Dairy Sci. 98:2611-2626.

Kim, K. H., and M. S. Lee. 2014. FGF21 as a stress hormone: The roles of FGF21 in stress adaptation and the treatment of metabolic diseases. Diabetes Metab. J. 38:245-251.

Kuznetsova, A., P. B. Brockhoff, and R. H. B. Christensen. 2014. lmerTest: Tests in Linear Mixed Effects Models. R package ver- sion 2.0-20. Accessed Feb. 3, 2015. http://CRAN.R-project.org/ package $=$ lmerTest

Lee, J. S., Z. Zheng, R. Mendez, S. W. Ha, Y. Xie, and K. Zhang. 2012. Pharmacologic ER stress induces non-alcoholic steatohepatitis in an animal model. Toxicol. Lett. 211:29-38.

Lenth, R. V., and M. Hervé. 2013. lsmeans: Least squares means. R package version 2.13. http://CRAN.R-project.org/package=lsmeans.

Li, X., Y. Yang, S. Liu, J. Yang, C. Chen, and Z. Sun. 2014. Grape seed extract supplementation attenuates the heat stress-induced responses of jejunum epithelial cells in Simmental x Qinchuan steers. Br. J. Nutr. 112:347-357.

Moate, P. J., S. R. Williams, V. A. Torok, M. C. Hannah, B. E. Ribaux, M. H. Tavendale, R. J. Eckard, J. L. Jacobs, M. J. Auldist, and W. J. Wales. 2014. Grape marc reduces methane emissions when fed to dairy cows. J. Dairy Sci. 97:5073-5087.

Nudda, A., F. Correddu, A. Marzano, G. Battacone, P. Nicolussi, P. Bonelli, and G. Pulina. 2015. Effects of diets containing grape seed, linseed, or both on milk production traits, liver and kidney activities, and immunity of lactating dairy ewes. J. Dairy Sci. 98:1157-1166

Pagliassotti, M. J. 2012. Endoplasmic reticulum stress in nonalcoholic fatty liver disease. Annu. Rev. Nutr. 32:17-33.

Patra, A. K., and J. Saxena. 2011. Exploitation of dietary tannins to improve rumen metabolism and ruminant nutrition. J. Sci. Food Agric. 91:24-37.

Plaizier, J. C., D. O. Krause, G. N. Gozho, and B. W. McBride. 2008. Subacute ruminal acidosis in dairy cows: The physiological causes, incidence and consequences. Vet. J. 176:21-31.

R Core Team. 2014. R: A language and environment for statistical computing. R Foundation for Statistical Computing, Vienna, Austria. http://www.R-project.org/.

Rath, E., and D. Haller. 2011. Inflammation and cellular stress: A mechanistic link between immune-mediated and metabolically driven pathologies. Eur. J. Nutr. 50:219-233.

Re, R., N. Pellegrini, A. Proteggente, A. Pannala, M. Yang, and C. Rice-Evans. 1999. Antioxidant activity applying an improved ABTS radical cation decolorization assay. Free Radic. Biol. Med. 26:1231-1237.

Ringseis, R., D. K. Gessner, and K. Eder. 2015. Molecular insights into the mechanisms of liver-associated diseases in early-lactating dairy cows: Hypothetical role of endoplasmic reticulum stress. J. Anim. Physiol. Anim. Nutr. (Berl.) http://dx.doi.org/10.1111/jpn.12263.

Rodriguez, J., H. Gilson, C. Jamart, D. Naslain, N. Pierre, L. Deldicque, and M. Francaux. 2015. Pomegranate and green tea extracts protect against ER stress induced by a high-fat diet in skeletal muscle of mice. Eur. J. Nutr. http://dx.doi.org/10.1007/s00394014-0717-9.

Ron, D., and P. Walter. 2007. Signal integration in the endoplasmic reticulum unfolded protein response. Nat. Rev. Mol. Cell Biol. $8: 519-529$.

Samali, A., U. Fitzgerald, S. Deegan, and S. Gupta. 2010. Methods for monitoring endoplasmic reticulum stress and the unfolded protein response. Int. J. Cell Biol. 2010:830307.

Santos, N. W., G. T. D. Santos, D. C. Silva-Kazama, P. A. Grande, P. M. Pintro, F. E. de Marchi, C. C. Jobim, and H. V. Petit. 2014. Production, composition and antioxidants in milk of dairy cows fed diets containing soybean oil and grape seed residue silage. Livest. Sci. 159:37-45.

Schaap, F. G., A. E. Kremer, W. H. Lamers, P. L. Jansen, and I. C. Gaemers. 2013. Fibroblast growth factor 21 is induced by endoplasmic reticulum stress. Biochimie 95:692-699.

Schlegel, G., R. Ringseis, J. Keller, F. J. Schwarz, W. Windisch, and K. Eder. 2012. Expression of fibroblast growth factor 21 in the liver of dairy cows in the transition period and during lactation. J. Anim. Physiol. Anim. Nutr. (Berl.) 97:820-829.

Schoenberg, K. M., S. L. Giesy, K. J. Harvatine, M. R. Waldron, C. Cheng, A. Kharitonenkov, and Y. R. Boisclair. 2011. Plasma FGF21 is elevated by the intense lipid mobilization of lactation. Endocrinology 152:4652-4661.

Shabtay, A., H. Eitam, Y. Tadmor, A. Orlov, A. Meir, P. Weinberg, Z. G. Weinberg, Y. Chen, A. Brosh, I. Izhaki, and Z. Kerem. 2008. 
Nutritive and antioxidative potential of fresh and stored pomegranate industrial byproduct as a novel beef cattle feed. J. Agric. Food Chem. 56:10063-10070.

Sidwell, C. G., H. Salwin, M. Benca, and J. H. Mitchell. 1954. The use of thiobarbituric acid as a measure of fat oxidation. J. Am. Oil Chem. Soc. 31:603-606.

Singleton, V. L., and J. Rossi. 1965. Colorimetry of total phenolics with phosphomolybdic-phosphotungstic acid reagents. Am. J. Enol. Vitic. 16:144-158.

Terra, X., G. Montagut, M. Bustos, N. Llopiz, A. Ardevol, C. Blade, J. Fernandez-Larrea, G. Pujadas, J. Salvado, L. Arola, and M. Blay. 2009. Grape-seed procyanidins prevent low-grade inflammation by modulating cytokine expression in rats fed a high-fat diet. J. Nutr. Biochem. 20:210-218.

van Knegsel, A. T., H. van den Brand, J. Dijkstra, S. Tamminga, and B. Kemp. 2005. Effect of dietary energy source on energy balance, production, metabolic disorders and reproduction in lactating dairy cattle. Reprod. Nutr. Dev. 45:665-688.

Van Soest, P. J., J. B. Robertson, and B. A. Lewis. 1991. Methods for dietary fiber, neutral detergent fiber, and nonstarch polysaccharides in relation to animal nutrition. J. Dairy Sci. 74:3583-3597.

Vandesompele, J., K. De Preter, F. Pattyn, B. Poppe, N. Van Roy, A. De Paepe, and F. Speleman. 2002. Accurate normalization of real-time quantitative RT-PCR data by geometric averaging of multiple internal control genes. Genome Biol 3:RESEARCH0034.
VDLUFA (Verband Deutscher Landwirtschaftlicher Untersuchungsund Forschungsanstalten). 2007. VDLUFA-Methodenbuch. Band III: Die chemische Untersuchung von Futtermitteln. Ergänzungslieferungen von 1983, 1988, 1992, 1997, 2004, 2006, 2007. VDLUFA, Darmstadt, Germany.

Vels, L., C. M. Rontved, M. Bjerring, and K. L. Ingvartsen. 2009. Cytokine and acute phase protein gene expression in repeated liver biopsies of dairy cows with a lipopolysaccharide-induced mastitis. J. Dairy Sci. 92:922-934.

Woodward, S. L., M. J. Auldist, P. J. Laboyrie, and E. B. L. Jansen 1999. Effect of Lotus corniculatus and condensed tannins on milk yield and milk composition of dairy cows. Proc. N.Z. Soc. Anim. Prod. 59:152-155.

Wu, C. X., R. Liu, M. Gao, G. Zhao, S. Wu, and G. H. Du. 2013. Pinocembrin protects brain against ischemia/reperfusion injury by attenuating endoplasmic reticulum stress induced apoptosis. Neurosci. Lett. 546:57-62.

Zebeli, Q., and B. U. Metzler-Zebeli. 2012. Interplay between rumen digestive disorders and diet-induced inflammation in dairy cattle. Res. Vet. Sci. 93:1099-1108.

Zhang, K., and R. J. Kaufman. 2008. From endoplasmic-reticulum stress to the inflammatory response. Nature 454:455-462. 